\title{
OPEN Ocean warming and acidification modify top-down and bottom-up control in a tropical seagrass ecosystem
}

\begin{abstract}
Vina Listiawati ${ }^{1,2,3}$ \& Haruko Kurihara ${ }^{1 凶}$
Seagrass ecosystem is one of the most productive ecosystems in coastal waters providing numerous ecological functions and supporting a large biodiversity. However, various anthropogenic stressors including climate change are impacting these vulnerable habitats. Here, we investigated the independent and combined effects of ocean warming and ocean acidification on plant-herbivore interactions in a tropical seagrass community. Direct and indirect effects of high temperature and high $p \mathrm{CO}_{2}$ on the physiology of the tropical seagrass Thalassia hemprichii and sea urchin Tripneustes gratilla were evaluated. Productivity of seagrass was found to increase under high $p \mathrm{CO}_{2}$, while sea urchin physiology including feeding rate decreased particularly under high temperature. The present study indicated that future climate change will affect the bottom-up and top-down balance, which potentially can modify the ecosystem functions and services of tropical seagrass ecosystems.
\end{abstract}

Seagrass ecosystems are classified as one of the most productive ecosystems in coastal waters ${ }^{1}$ and provide numerous ecological functions including regulation of the nutrient cycle ${ }^{2}$, carbon sink ${ }^{3}$, sediment stabilization ${ }^{4}$, and habitats and food provision for a wide range of marine organisms ${ }^{5}$. However, seagrass ecosystems are now threatened by a number of anthropogenic stressors, such as eutrophication, dredging and coastal development ${ }^{6}$. In addition to such local stressors, the ongoing global ocean environmental change caused by increasing atmospheric $\mathrm{CO}_{2}$ is expected to intensely affect seagrass ecosystems worldwide ${ }^{7}$. Therefore, information on how global climate change including ocean warming and acidification will affect seagrass meadows is critical to enable prediction and implementation of effective conservation strategies of seagrass ecosystems ${ }^{8}$.

Increase of seawater temperature is generally known to increase seagrass metabolism and productivity ${ }^{9,10}$. However, seagrass species are known to have a thermal tolerance window ${ }^{11}$, and temperature that exceed this window will negatively or potentially lethally affect them ${ }^{12,13}$. Meanwhile, ocean acidification has been suggested to benefit seagrasses and increase their productivity ${ }^{14-16}$ because photosynthesis of most seagrasses has been shown to be undersaturated at present seawater partial pressure of $\mathrm{CO}_{2}\left(p \mathrm{CO}_{2}\right)^{17}$. Therefore, although most studies have addressed the positive effects of ocean acidification on seagrasses, these benefits could be negated under the more realistic scenario of ocean acidification combined with an increase in temperature ${ }^{18}$.

What is less clearly established is how climate change will affect seagrass ecosystems through biological interactions such as between plant and herbivores ${ }^{19}$. For example, increase in temperature can increase the metabolism of herbivores in seagrass ecosystems such as keystone species of sea urchins, resulting in increased grazing pressure by the herbivores on the seagrass ${ }^{20}$. However, the grazing pressure can also be decreased due to ocean acidification through negative impacts on the herbivores ${ }^{21,22}$. Ocean acidification can also alter the C:N ratio and secondary metabolites such as phenolic and tannin of seagrass ${ }^{18,23}$ which may alter the plant's resistance to herbivores. Therefore, it can be suggested that the combined effects of ocean warming and acidification will alter the top-down control of herbivores and the bottom-up control by the seagrass, which may result in a change in the equilibrium regulating seagrass ecosystems. However, to our knowledge, there are only two laboratory studies that have evaluated the effects of ocean acidification ${ }^{19,24}$ and one study ${ }^{20}$ evaluating the effect of ocean acidification and warming on interactions among seagrass and its consumers. Additionally, all studies are restricted to temperate species and there is no work addressing the effects of ocean warming and acidification on the tropical seagrass-herbivore interactions. Tropical seagrass species could be particularly sensitive to climate

${ }^{1}$ Faculty of Science, University of the Ryukyus, Okinawa 903-0123, Japan. ${ }^{2}$ Master of Marine Science, Universitas Diponegoro, Semarang 50275, Indonesia. ${ }^{3}$ Department of Biology Education, Universitas Muhammadiyah Surakarta, Surakarta 57162, Indonesia. ${ }^{\boxplus}$ email: harukoku@sci.u-ryukyu.ac.jp 
a

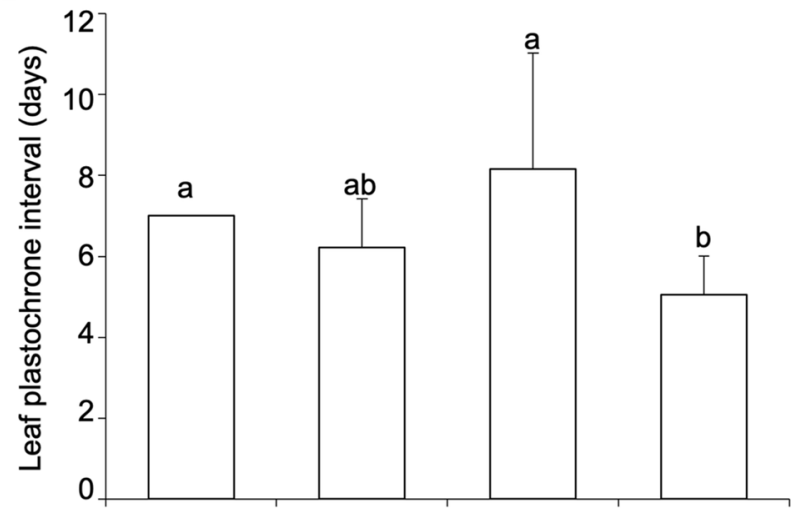

b

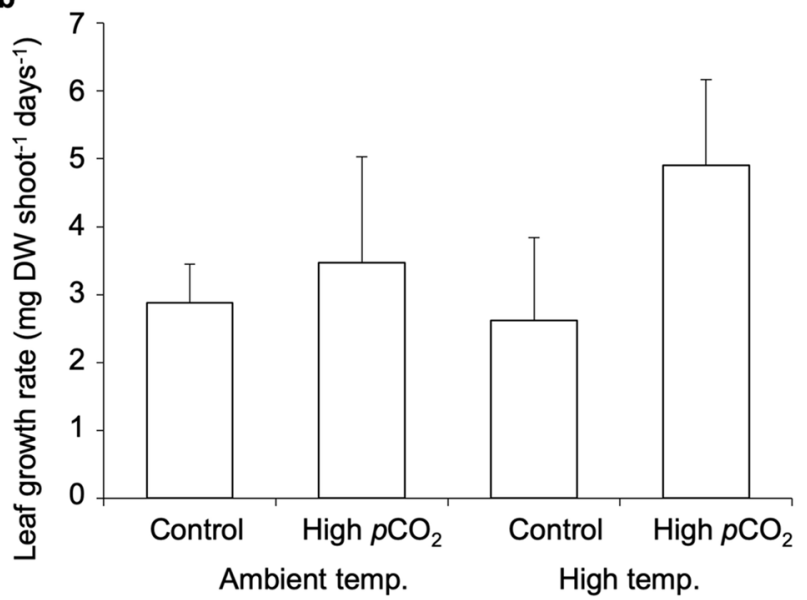

Figure 1. Effect of high temperature $\left(+3^{\circ} \mathrm{C}\right.$ than ambient $)$ and high $p \mathrm{CO}_{2}(1000 \mu$ atm $)$ on the plasctochrone interval and growth rate of seagrass Thalassia hemprichii. (a) leaf plastochrone interval $\left(\mathrm{P}_{\mathrm{L}}\right)$; and (b) leaf growth rate. Values represent mean \pm SD. $n=6$. Different letters indicate statistically significant differences among treatment (Tukey's HSD post-hoc test).

change, as most species may already be living at temperature close to their thermal limit ${ }^{25}$. Changes in seagrass abundances would have cascading effects over the entire ecosystem and therefore it is essential to evaluate the effects of climate change on tropical species interactions.

Here we investigate the independent and combined effects of ocean warming and acidification on both tropical seagrass species Thalassia hemprichii [(Ehrenberg) Ascherson, 1871] and sea urchin Tripneustes gratilla (Linnaeus, 1758) and their potential synergistic interactions. We designed a laboratory-based experiment in which seagrass and sea urchins were cultured under controlled high temperature (plus $3{ }^{\circ} \mathrm{C}$ than control) and high $p \mathrm{CO}_{2}(900-1000 \mu \mathrm{atm})$. We hypothesized that although the productivity of $T$. hemprichii will be enhanced by both high temperature and high $p \mathrm{CO}_{2}$ conditions, the feeding ability of T. gratilla will be enhanced by high temperature while it will be reduced by high $p \mathrm{CO}_{2}$ conditions. We first tested the direct effects of warming and acidification on the productivity and photo-physiological responses of the seagrass. Secondly, we examined the physiology including feeding, fecal production, respiration and ammonium $\left(\mathrm{NH}_{4}^{+}\right)$excretion rates of sea urchins cultured under warming and/or acidification conditions and fed with two seagrass treatments; control seagrass which were cultured under the ambient control condition and experimental seagrass which were cultured under the same warming and/or acidification conditions as the sea urchins were cultured.

\section{Results}

Seagrass growth. There was a significant interaction between $p \mathrm{CO}_{2}$ and temperature on leaf plastochrone interval $\left(\mathrm{P}_{\mathrm{L}}\right)$ of Thalassia hemprichii $\left(\mathrm{GLM}: \mathrm{F}_{(1,20)}=4.627, p=0.044\right)$ and the shortest $\mathrm{P}_{\mathrm{L}}(5.056 \pm 0.952$ days) was observed at high temperature and high $p \mathrm{CO}_{2}$ combined conditions (Tukey's HSD post-hoc test: $p<0.05$, Fig. 1a, Supplementary Table S1). High $p \mathrm{CO}_{2}$ significantly increased the leaf growth rate (two-way ANOVA: $\left.\mathrm{F}_{(1,20)}=8.472, p=0.009\right)$, while there was no effects of temperature and interactive effects between the two factors (two-way ANOVA: $p>0.05$, Fig. 1b, Supplementary Table S2).

Seagrass photo-physiology. High $p \mathrm{CO}_{2}$ significantly increased $\mathrm{F}_{\mathrm{v}} / \mathrm{F}_{\mathrm{m}}$ of T. hemprichii (two-way ANOVA: $\left.\mathrm{F}_{(1,20)}=4.954, p=0.038\right)$, while there was no significant effect of high temperature and interaction between $p \mathrm{CO}_{2}$ and temperature (two-way ANOVA: $p>0.05$, Table 1, Supplementary Table S3). The relative electron transport 


\begin{tabular}{|l|l|l|l|l|}
\hline \multirow{2}{*}{ Photo-physiological parameters } & \multicolumn{3}{|l|}{ Ambient temperature } & \multicolumn{2}{l|}{ High temperature } \\
\cline { 2 - 6 } & \multicolumn{1}{l}{ Control } & High $p \mathrm{CO}_{2}$ & Control & High $\boldsymbol{p} \mathrm{CO}_{2}$ \\
\hline $\mathrm{F}_{\mathrm{v}} / \mathrm{F}_{\mathrm{m}}$ & $0.727 \pm 0.026$ & $0.741 \pm 0.022$ & $0.670 \pm 0.098$ & $0.770 \pm 0.060$ \\
\hline$\alpha$ & $0.16 \pm 0.06$ & $0.2 \pm 0.06$ & $0.15 \pm 0.03$ & $0.29 \pm 0.07$ \\
\hline$\beta$ & $0.003 \pm 0.002$ & $0.005 \pm 0.004$ & $0.005 \pm 0.003$ & $0.007 \pm 0.003$ \\
\hline $\mathrm{rETR}_{\max }$ & $32.58 \pm 4.49$ & $43.57 \pm 7.60$ & $34.46 \pm 6.02$ & $48.20 \pm 9.27$ \\
\hline $\mathrm{E}_{\mathrm{k}}$ & $239 \pm 123$ & $220 \pm 44$ & $241 \pm 71$ & $167 \pm 33$ \\
\hline
\end{tabular}

Table 1. Effect of high temperature $\left(+3{ }^{\circ} \mathrm{C}\right.$ than ambient $)$ and high $p \mathrm{CO}_{2}(1000 \mu \mathrm{atm})$ on photo-physiological parameters of seagrass Thalassia hemprichii. Values represent mean \pm SD. $n=6$.

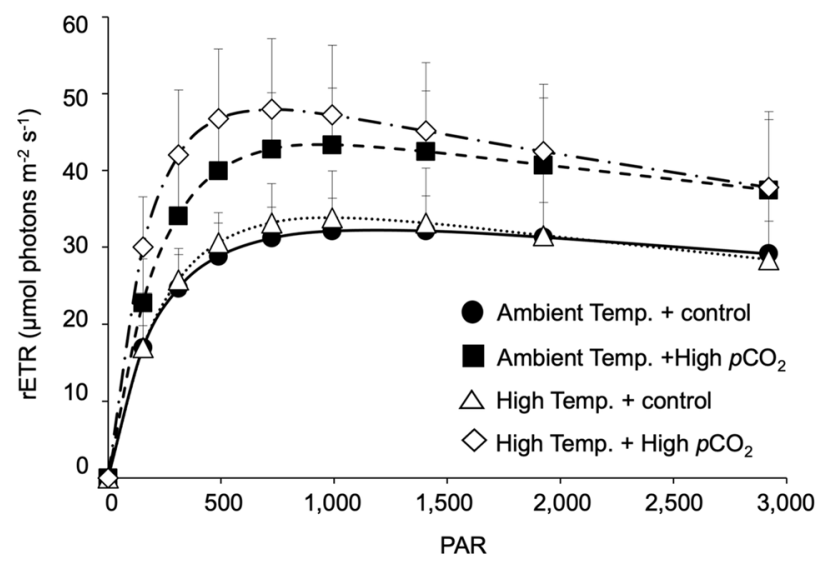

Figure 2. Effect of high temperature $\left(+3{ }^{\circ} \mathrm{C}\right.$ than ambient $)$ and high $p \mathrm{CO}_{2}(1000 \mu \mathrm{atm})$ on rapid light curves (RLC) of seagrass Thalassia hemprichii. Values represent mean \pm SD. $n=6$.

rate (rETR) value was highest for T. hemprichii cultured under the high temperature and high $p \mathrm{CO}_{2}$ combined condition (Fig. 2). Photo-physiological responses including $\alpha$ and $\mathrm{rETR}_{\max }$ of T. hemprichii were significantly higher at high $p \mathrm{CO}_{2}$ (two-way ANOVA: $\alpha, \mathrm{F}_{(1,20)}=13.788, p=0.001 ; \mathrm{rETR}_{\max }, \mathrm{F}_{(1,20)}=18.286, p<0.001$ ) with no significant effect of high temperature and interaction between $p \mathrm{CO}_{2}$ and temperature (two-way ANOVA: $p>0.05$ ). There was no effect of high $p \mathrm{CO}_{2}$ and temperature on $\beta$ and $\mathrm{E}_{\mathrm{k}}$ (two-way ANOVA: $p>0.05$; Table 1, Supplementary Table S3).

Seagrass carbon and nitrogen content. High temperature significantly decreased the above-ground leaf C:N ratio of T. hemprichii (two-way ANOVA: $\mathrm{F}_{(1,20)}=21.756, p<0.001$ ), while there was no significant effect of high $p \mathrm{CO}_{2}$ and interaction between $p \mathrm{CO}_{2}$ and temperature (two-way ANOVA: $p>0.05$, Fig. 3, Supplementary Table S4). Decreased C:N ratio at high temperature was caused by the significant increase of leaf nitrogen content, while leaf carbon content was not affected by both high temperature and high $p \mathrm{CO}_{2}$ (Supplementary Fig. S1a,c, Supplementary Table S4). The carbon content of below-ground part significantly decreased by high temperature, while there was no significant effect of $p \mathrm{CO}_{2}$ or interaction between temperature and $p \mathrm{CO}_{2}$ (Supplementary Fig. S1b, Supplementary Table S4). The nitrogen content of the below-ground part was significantly lower at high $\mathrm{pCO}_{2}$, with no significant effect of high temperature or interaction between the two factors (Supplementary Fig. S1d, Supplementary Table S4).

Sea urchin feeding and fecal production rates. The feeding rate of sea urchin T. gratilla showed significant interactive effects between $p \mathrm{CO}_{2}$ and temperature $\left(\mathrm{GLM}: \mathrm{F}_{(1,68)}=6.428, p=0.014\right.$, Supplementary Table S5), and between the seagrass sources and temperature (GLM: $F_{(1,66)}=8.114, p=0.006$, Supplementary Table S5). T. gratilla showed the lowest feeding rate when cultured under high temperature and fed with seagrass cultured under high temperature conditions (Fig. 4a, Supplementary Table S5). Fecal production rate of T. gratilla showed significant interactive effects between $p \mathrm{CO}_{2}$ and temperature (three-way ANOVA: $\mathrm{F}_{(1,65)}=6.460, p=0.013$, Fig. 4b, Supplementary Table S6). Additionally, seagrass treatments significantly affected the fecal production rate (three-way ANOVA: $\mathrm{F}_{(1,65)}=6.171, p=0.016$; Fig. 4b, Supplementary Table S6).

Absorption efficiencies of carbon and nitrogen showed significant interaction between $p \mathrm{CO}_{2}$ and temperature, while there was no significant effect of seagrass treatments (Supplementary Fig. S2a, b, Supplementary Table S7).

Sea urchin respiration and ammonium $\left(\mathrm{NH}_{4}{ }^{+}\right)$excretion rate. There was an interaction between $p \mathrm{CO}_{2}$ and temperature on the respiration rate of T. gratilla (three-way ANOVA: $\mathrm{F}_{(1,61)}=4.655, p=0.035$; Fig. 5a and Supplementary Table S8). Additionally, respiration rate of T. gratilla was also interactively affected by 


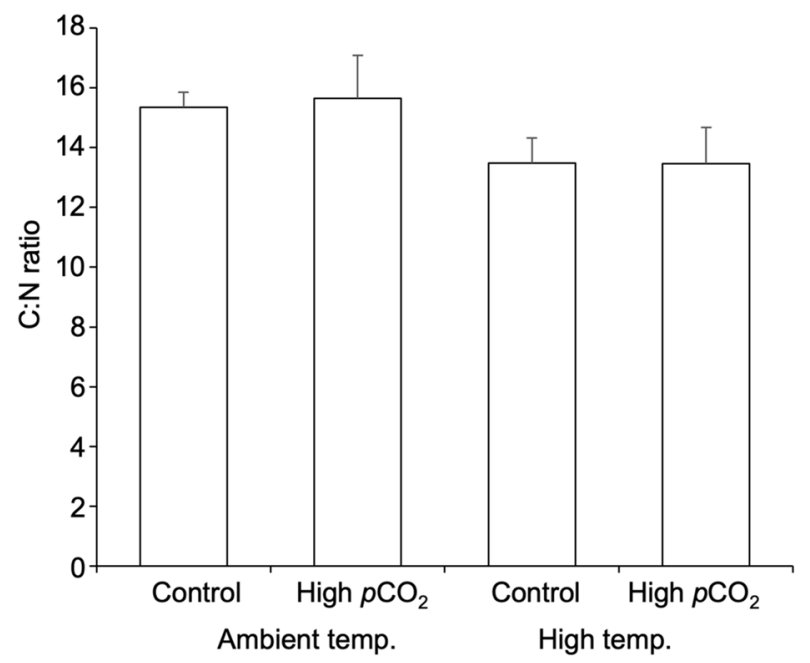

Figure 3. Effect of high temperature $\left(+3^{\circ} \mathrm{C}\right.$ than ambient $)$ and high $p \mathrm{CO}_{2}(1000 \mu$ atm $)$ on the leaf C: $\mathrm{N}$ ratio of seagrass Thalassia hemprichii. Values represent mean \pm SD. $n=6$.
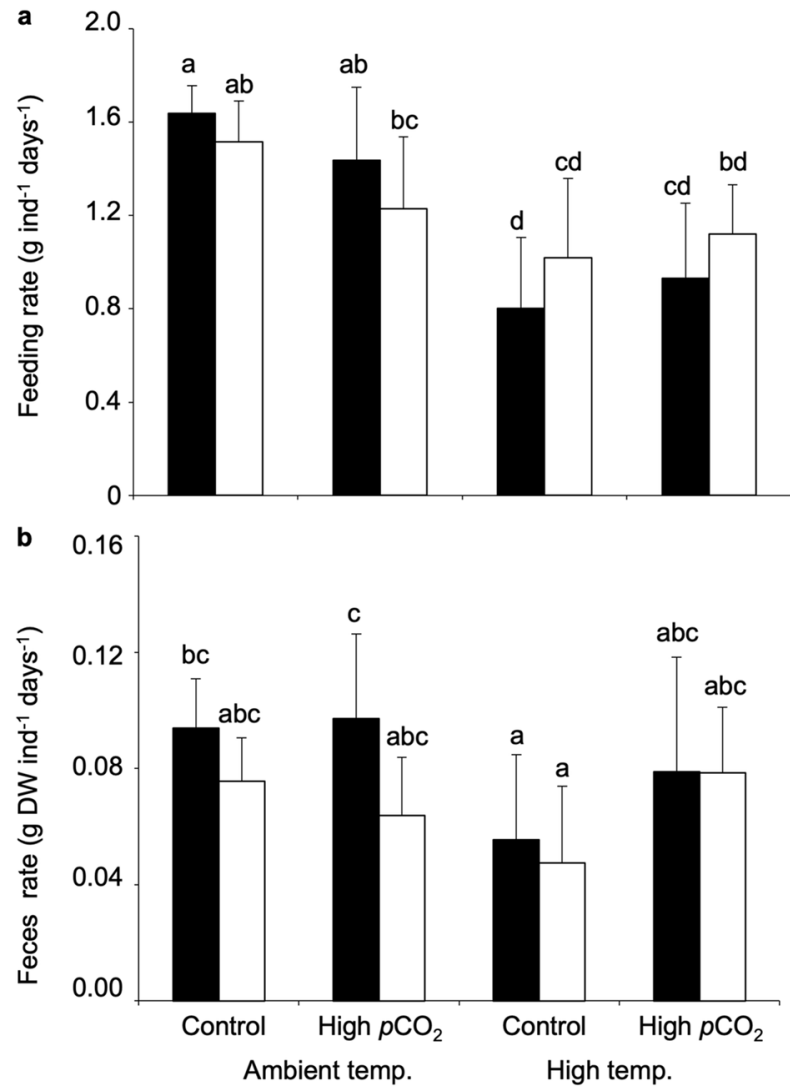

Figure 4. Effect of high temperature $\left(+3{ }^{\circ} \mathrm{C}\right.$ than ambient $)$ and high $p \mathrm{CO}_{2}(1000 \mu \mathrm{atm})$ on feeding and fecal production rate of sea urchin Tripneustes gratilla. (a) Feeding rate and (b) fecal production rate of T. gratilla fed with experimental (black) and control (white) seagrass. Values represent mean \pm SD. Ambient temperature and Control $p \mathrm{CO}_{2}$ (experimental seagrass: $\mathrm{n}=10$, control seagrass: $\mathrm{n}=9$ ), Ambient temperature and High $p \mathrm{CO}_{2}$ (experimental seagrass: $n=9$, control leaves: $n=9$ ), High temperature and Control $p \mathrm{CO}_{2}$ (experimental seagrass: $\mathrm{n}=10$, control seagrass: $\mathrm{n}=8$ ), High temperature and High $p \mathrm{CO}_{2}$ (experimental seagrass: $\mathrm{n}=10$, control seagrass: $n=8$ ). Different letters indicate statistically significant differences among conditions (Tukey's HSD post-hoc test). 


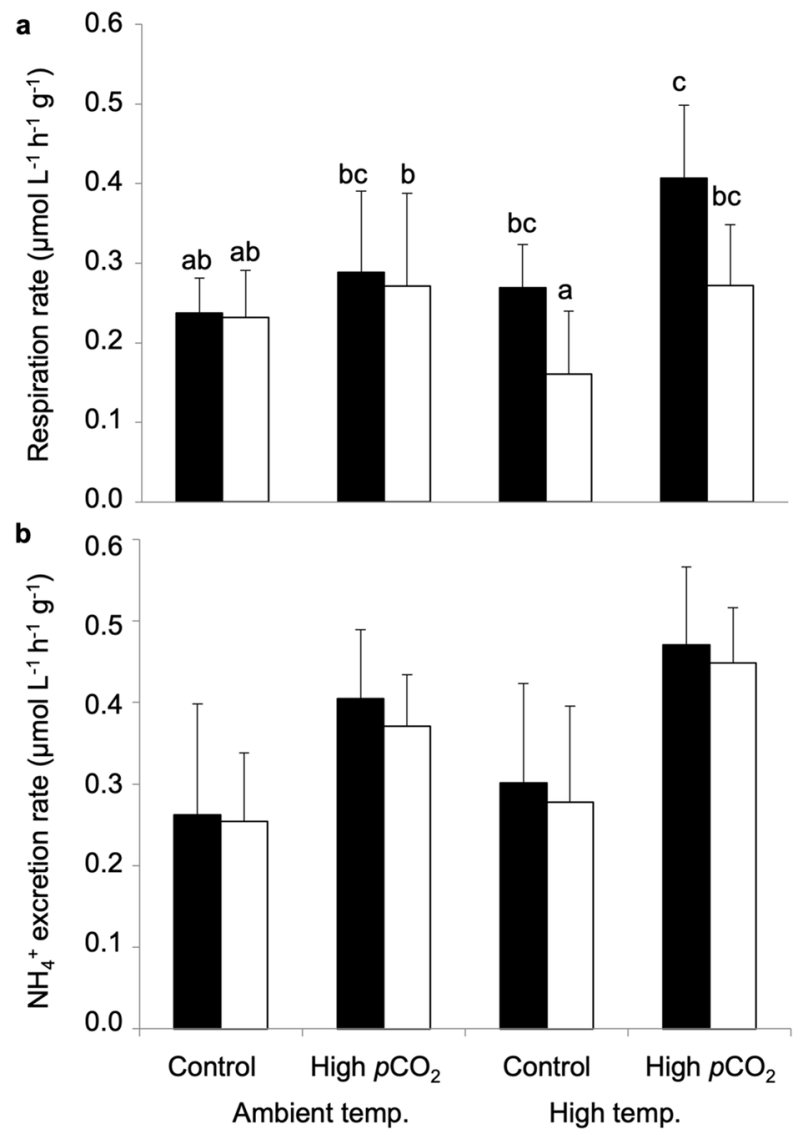

Figure 5. Effect of high temperature $\left(+3^{\circ} \mathrm{C}\right.$ than ambient $)$ and high $p \mathrm{CO}_{2}(1000 \mu \mathrm{atm})$ on respiration and ammonium excretion rates of sea urchin Tripneustes gratilla. (a) Respiration rate and (b) ammonium $\left(\mathrm{NH}_{4}{ }^{+}\right)$ excretion rate of $T$. gratilla fed with experimental (black) and control (white) seagrass. Values represent mean \pm SD. Ambient temperature and Control $p \mathrm{CO}_{2}$ (experimental seagrass: $\mathrm{n}=9$, control seagrass: $\mathrm{n}=9$ ), Ambient temperature and High $p \mathrm{CO}_{2}$ (experimental seagrass: $n=9$, control seagrass: $n=9$ ), High temperature and Control $p \mathrm{CO}_{2}$ (experimental seagrass: $\mathrm{n}=9$, control seagrass: $\mathrm{n}=8$ ), High temperature and High $p \mathrm{CO}_{2}$ (experimental seagrass: $n=8$, control seagrass: $n=8$ ). Different letters indicate statistically significant among conditions (Tukey's HSD post-hoc test).

the seagrass source and temperature (three-way ANOVA: $\mathrm{F}_{(1,61)}=8.294, p=0.005$; Fig. 5a and Supplementary Table S8). Ammonium $\left(\mathrm{NH}_{4}^{+}\right)$excretion rate of T. gratilla was significantly higher at high $p \mathrm{CO}_{2}$ (three-way ANOVA: $\mathrm{F}_{(1,61)}=37.880, p<0.001$; Fig. $5 \mathrm{~b}$ and Supplementary Table S8) and high temperature (three-way ANOVA: $\mathrm{F}_{(1,61)}=4.673, p=0.035$; Fig. $5 \mathrm{~b}$ and Supplementary Table S8), while there was no effect of seagrass treatments or interaction among $p \mathrm{CO}_{2}$, temperature, and seagrass treatments (three-way ANOVA: $p>0.05$, Supplementary Table S8).

\section{Discussion}

Increased seawater $p \mathrm{CO}_{2}$ was found to enhance the productivity of seagrass T. hemprichii. Meanwhile, the feeding rate of the tropical sea urchin T. gratilla on T. hemprichii significantly decreased particularly at high temperatures, suggesting a decrease in grazing pressure by this keystone herbivore in tropical seagrass meadows under ocean warming. These results indicate that climate change has the potential to cause a shift in the state of tropical seagrass meadows by changing both the bottom-up and top-down control.

Though increasing temperature can either positively or negatively affect seagrasses, photo-physiology and growth rate of $T$. hemprichii did not change at the high temperature condition. The optimum temperature for $T$. hemprichii at Santiago Islands, Philippines (annual temperature range of $24-33^{\circ} \mathrm{C}$ ) was reported to be around $27^{\circ} \mathrm{C}^{26}$. Taking into account that the annual temperature range at the present site in Okinawa Island ranges from 20 to $30^{\circ} \mathrm{C}^{27}$ and that the high temperature conditions did not show positive effects, it can be considered that the present high temperature condition $\left(32.5^{\circ} \mathrm{C}\right)$ was close to their upper thermal window range. Additionally, future temperature conditions may exceed the upper threshold of seagrass species that inhabit places with higher annual temperature including low latitude tropic regions. Consequently, although future increases of seawater temperature by $3{ }^{\circ} \mathrm{C}$ may not negatively impact T. hemprichii at Okinawa Island, further increases of temperature under ocean warming scenario may become deleterious to the seagrass. 
Similar to prior studies on seagrasses ${ }^{14-17}$, ocean acidification enhanced photosynthetic rate parameters and increased the productivity of $T$. hemprichii. Additionally, $\mathrm{rETR}_{\max }$ was also found to be enhanced under high $p \mathrm{CO}_{2}$ condition, following the finding that Rubisco activity of most seagrasses including T. hemprichii is undersaturated at the present $p \mathrm{CO}_{2}$ condition ${ }^{28}$. Therefore, it is predictable that ocean acidification will enhance the productivity of seagrass worldwide in the future. Interestingly, the $\mathrm{P}_{\mathrm{L}}$ of $T$. hemprichii was synergistically enhanced by high $p \mathrm{CO}_{2}$ and temperature, and rETR although not significant, showed the highest value at the combined condition. Synergistic response to high $p \mathrm{CO}_{2}$ and temperature was also reported for the temperate seagrass Zostera noltii where high $p \mathrm{CO}_{2}$ tends to ameliorate the negative effects of high temperature on seagrass productivity ${ }^{18}$. One of the potential explanations is that high $p \mathrm{CO}_{2}$ condition increases the Rubisco activity and electron transport capacity inducing shifts of the optimum temperature to a higher temperature as suggested for terrestrial $\mathrm{C}_{3}$ plants $^{29}$. Further studies are needed in order to evaluate those synergistic effects of temperature and $p \mathrm{CO}_{2}$ on seagrass.

In contrast to our hypothesis that sea urchin grazing will be enhanced by ocean warming and reduced by ocean acidification, here we found that high temperature reduced the feeding rate of T. gratilla while ocean acidification had no effect. Temperature rise is generally known to increase the feeding rate of herbivores due to the increase in their metabolic demands ${ }^{20,30}$. However, the respiration rate of T. gratilla did not change at the present high temperature condition $\left(32.5^{\circ} \mathrm{C}\right)$. Additionally, although increased temperature decreased the leaf C:N ratio, the feeding rate of $T$. gratilla fed both control and experimental seagrass decreased, suggesting direct negative effects of temperature on sea urchin physiology rather than indirect effects through seagrass nutrition. As such, it appears that T. gratilla populations in Okinawa are already living near their upper thermal limit and ocean warming will negatively affect $T$. gratilla, resulting in a decrease of grazing pressure on the seagrass.

Previous studies suggested that ocean acidification will decrease sea urchins feeding ability, because the exoskeletal structures including the feeding apparatus of sea urchins become more fragile when reared under high $p \mathrm{CO}_{2}$ condition ${ }^{22}$. Additionally, high $p \mathrm{CO}_{2}$ condition has been suggested to increase the C:N ratio of plants, although the effects of ocean acidification on seagrasses were not found to be uniform for both C:N ratio (increase $\mathrm{e}^{16,29,31}$ or no change ${ }^{19,20}$ ) and for phenolic level (no change ${ }^{19}$ or decrease $\mathrm{e}^{23}$ ). Here both feeding rate and fecal production rate of T. gratilla as well as $\mathrm{C}: \mathrm{N}$ ratio of $T$. hemprichii were not affected by high $p \mathrm{CO}_{2}$, however both respiration and $\mathrm{NH}_{4}^{+}$excretion rates of T. gratilla were found to increase. Although most previous studies have reported no clear effect of high $p \mathrm{CO}_{2}$ on sea urchin respiration ${ }^{21,32}$, increased $\mathrm{NH}_{4}{ }^{+}$excretion rate was also found in the sea urchin Strongylocentrotus drobachiensis ${ }^{33}$ and bivalves such as Mytilus edulis, which was suggested to indicate an increase of protein catabolism due to high $\mathrm{pCO}_{2}{ }^{34}$. These results suggest that although ocean acidification may not affect the grazing pressure of the sea urchin, it may affect the physiology of the sea urchin. Additionally, in terms of energy budget, it can be infered that increased respiration and $\mathrm{NH}_{4}{ }^{+}$excretion rates with no significant change in feeding rate at high $p \mathrm{CO}_{2}$ could decrease the amount of energy available for growth and reproduction of the sea urchin. Indeed some previous studies have indicated that exposure of sea urchin to high $p \mathrm{CO}_{2}$ resulted in a decrease of feeding rate and delay in gonad development ${ }^{21}$, or increased respiration and reduced gonadosomatic index particularly in female sea urchins ${ }^{35,36}$. Furthermore, a decrease in the available energy for T. gratilla could be particularly significant under the combination of ocean warming and acidification, considering the significant decrease in feeding rate with the synergistic increase in respiration rate under high temperature and $p \mathrm{CO}_{2}$ environment, especially when T. gratilla was fed with experimental seagrass.

The present study demonstrated that ocean warming and acidification can show different direct impacts on plants and herbivores. Productivity of the seagrass was found to increase with ocean acidification, while grazing pressure by the tropical sea urchin will decrease under climate change, which can result in modification of plant-herbivore interactions. Plant-herbivore interactions have been suggested to structure tropical seagrass meadows, and ecosystem services by the tropical seagrass ecosystem, such as carbon sequestration and nutrient up-take, are maximized under the balanced system that support both seagrass and herbivore diversity ${ }^{37,38}$. Therefore, any alteration in the top-down control by herbivores such as sea urchins and the bottom-up control by the seagrass due to climate change can potentially result in a shift in the equilibrium regulating seagrass ecosystems leading to change in ecosystem functions and services of tropical seagrass meadow. Moreover, these effects can also potentially be strengthened further by concomitant stressors such as coastal development, eutrophication and overfishing.

\section{Methods}

Study species. Seagrass Thalassia hemprichii (Ehrenberg) Ascherson, 1871 shoots and sediment were collected at Bise ( $26^{\circ} 42.548^{\prime}$, E $\left.127^{\circ} 52.740^{\prime}\right)$ in Okinawa Island, Japan in May 2014. After being transported to the Sesoko Station, University of the Ryukyus, each seagrass shoot was carefully washed to remove epiphytes and sediment.

Eighty juvenile sea urchins Tripneustes gratilla (Linnaeus, 1758) of the same age were obtained from Okinawa Prefectural Sea Farming Center, Okinawa Island, Japan in February 2014. The sea urchins were transported to the Sesoko Station and cultured for 4 months in 4 tanks ( $157 \mathrm{~L}, \mathrm{n}=20$ per tank) continuously supplied with filtered seawater $\left(2 \mathrm{~L} \mathrm{~min}^{-1}\right)$ and fed with Undaria pinnatifida every four days and were used as stock sea urchins for the following experiment.

Experimental design. Two temperature conditions; ambient temperature and high temperature $\left(+3{ }^{\circ} \mathrm{C}\right.$ higher than ambient) and $2 p \mathrm{CO}_{2}$ conditions; control $(300-400 \mu \mathrm{atm})$ and high $p \mathrm{CO}_{2}(900-1000 \mu$ atm) were selected as present and year 2100 conditions according to the IPCC RCP 8.5 scenario $^{41}$ (Table 2). Ambient seawater temperature fluctuated following field seawater by using flowing seawater pumped from $4-5 \mathrm{~m}$ depth in the front of the station. High temperature condition was controlled using heaters to be always $3{ }^{\circ} \mathrm{C}$ higher than 


\begin{tabular}{|c|c|c|c|c|c|c|c|c|}
\hline Condition & & 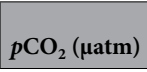 & $\begin{array}{l}\text { pH (NBS } \\
\text { scale) }\end{array}$ & $\begin{array}{l}\text { Temperature } \\
\left({ }^{\circ} \mathrm{C}\right)\end{array}$ & Salinity & TA $(\mu \mathrm{mol} / \mathrm{kg})$ & $\begin{array}{l}\text { DIC ( } \mu \mathrm{mol} / \\
\mathrm{kg})\end{array}$ & Sar \\
\hline \multicolumn{9}{|l|}{ T. hemprichii } \\
\hline \multirow{2}{*}{ Ambient Temp } & Control & $304 \pm 42$ & $8.27 \pm 0.05$ & $29.4 \pm 1.6$ & $34.2 \pm 0.1$ & $2231 \pm 14$ & $1848 \pm 32$ & $4.29 \pm 0.38$ \\
\hline & High $p \mathrm{CO}_{2}$ & $988 \pm 219$ & $7.85 \pm 0.09$ & $29.3 \pm 1.6$ & $34.2 \pm 0.1$ & $2232 \pm 13$ & $2075 \pm 33$ & $2.03 \pm 0.39$ \\
\hline \multirow{2}{*}{ High Temp } & Control & $337 \pm 45$ & $8.24 \pm 0.05$ & $32.4 \pm 1.6$ & $34.2 \pm 0.1$ & $2231 \pm 13$ & $1844 \pm 30$ & $4.42 \pm 0.42$ \\
\hline & High $p \mathrm{CO}_{2}$ & $930 \pm 166$ & $7.88 \pm 0.07$ & $32.4 \pm 1.6$ & $34.2 \pm 0.1$ & $2233 \pm 13$ & $2048 \pm 30$ & $2.34 \pm 0.35$ \\
\hline \multicolumn{9}{|l|}{ T. gratilla } \\
\hline \multirow{2}{*}{ Ambient Temp } & Control & $375 \pm 31$ & $8.2 \pm 0.03$ & $28.7 \pm 0.9$ & $34.2 \pm 0.2$ & $2239 \pm 10$ & $1908 \pm 19$ & $3.74 \pm 0.16$ \\
\hline & High $p \mathrm{CO}_{2}$ & $895 \pm 135$ & $7.89 \pm 0.06$ & $28.7 \pm 0.9$ & $34.2 \pm 0.2$ & $2242 \pm 12$ & $2074 \pm 21$ & $2.11 \pm 0.30$ \\
\hline \multirow{2}{*}{ High Temp } & Control & $390 \pm 31$ & $8.19 \pm 0.03$ & $31.8 \pm 0.8$ & $34.2 \pm 0.2$ & $2239 \pm 11$ & $1890 \pm 20$ & $4.01 \pm 1.60$ \\
\hline & High $p \mathrm{CO}_{2}$ & $925 \pm 137$ & $7.88 \pm 0.06$ & $31.8 \pm 0.7$ & $34.2 \pm 0.2$ & $2240 \pm 9$ & $2059 \pm 24$ & $2.3 \pm 0.28$ \\
\hline
\end{tabular}

Table 2. Seawater carbonate chemistry during seagrass Thalassia hemprichii and sea urchin Tripneustes gratilla culture. Seawater $p \mathrm{CO}_{2}$, DIC and $\Omega_{\mathrm{ar}}$ were calculated from the measured $\mathrm{pH}$ and total alkalinity (TA) using $\mathrm{CO} 2 \mathrm{SYS}$. Values represent mean $\pm \mathrm{SD}$.

the control. Seawater $p \mathrm{CO}_{2}$ was adjusted by bubbling seawater with air (control) or with a mixture of air and pure $\mathrm{CO}_{2}$ gas (high $p \mathrm{CO}_{2}$ ) controlled by mass flow controllers (Horiba Stec, SEC-E40, Japan). Both seagrass and sea urchins were acclimated for 40 days under the 2 temperatures and 2 seawater $p \mathrm{CO}_{2}$ full factorial design giving 4 experimental conditions before starting the measurements.

Just after collection, the T. hemprichii were cut into one apical shoot with two rhizome internodes and roots, and 48 shoots were planted in each of 24 aquaria ( $12 \mathrm{~L}$ ) containing $5 \mathrm{~cm}$ sediment thickness to mimic the density of T. hemprichii at the Bise site. Six aquaria were used as replicates for each of the 4 experimental conditions. The 4 experimental seawater conditions were continuously supplied $\left(0.5 \mathrm{~L} \mathrm{~min}^{-1}\right)$ to each of the 6 aquaria, and T. hemprichii were cultured for 40 days under natural sunlight until conducting the following measurements.

For the sea urchin, 40 individuals (3-4 cm diameter) were randomly selected from the stock and put individually in 40 containers $(900 \mathrm{~mL})$ with a mesh cage cylindrical lining inside each container. Replicate 10 containers received the 4 experimental seawater conditions $\left(0.1 \mathrm{~L} \mathrm{~min}^{-1}\right)$ and $T$. gratilla were cultured for 40 days in the laboratory under 12:12 $\mathrm{h}$ photoperiod artificial light $\left(100 \mu \mathrm{mol}\right.$ photons $\left.\mathrm{m}^{-2} \mathrm{~s}^{-1}\right)$ controlled by 2 metal-halide lamps (W039-006P, Iwasaki, Japan). Sea urchins were fed with Undaria pinnatifida during the acclimation about once every 4 days.

During the seagrass and sea urchin culture, seawater $\mathrm{pH}$ (NBS scale), temperature, and salinity of each aquarium and containers were measured (14:00-15:00 h) using a multiparameter portable meter (WTW Multi 3420 , Germany) connected with a temperature-compensated pH electrode (SenTix 940) and conductivity electrode (TetraCon 925). For total alkalinity (TA), seawater samples were taken every 2-3 days and measured using an auto-burrete titrator (Kimoto, ATT-05, Japan). Seawater $\mathrm{pCO}_{2}$ and $\Omega_{\text {aragonite }}$ were calculated based on $\mathrm{pH}$, temperature, salinity, and TA data using CO2SYS ver. 2.1 program $^{39}$ with $\mathrm{K} 1$ and $\mathrm{K} 2$ dissociation constants from Mehrbach recalculated by Dickson and Millero ${ }^{40}$ (Table 2).

Seagrass leaf growth. The leaf growth of T. hemprichii was measured by the leaf plastochrone interval $\left(\mathrm{P}_{\mathrm{L}}\right)$ method $^{41}$. After all the following sea urchin feeding experiments were finished, one apical seagrass shoot was chosen randomly from each of the 24 aquaria and punched using a needle at $1 \mathrm{~cm}$ from the lower part of the bundle sheath. The punched shoots were replanted into the aquarium and cultured for a further 14 days under the 4 experimental conditions. Thereafter, all 24 punched seagrass shoots were recollected, and $\mathrm{P}_{\mathrm{L}}$ was calculated by dividing the number of days since marking (14 days) with the number of new leaves (unmarked leaves higher than the punch mark). Leaf growth ( $\mathrm{mg} \mathrm{dry} \mathrm{wt} \mathrm{shoot}^{-1}$ day $^{-1}$ ) was calculated by dividing the dry weight measured using an electronic balance (HR-200, A\&D, Japan) of the youngest mature leaf (the third leaf) dried $\left(60^{\circ} \mathrm{C}\right)$ for 7 days by the leaf $\mathrm{P}_{\mathrm{L}}$.

Seagrass photo-physiological responses. The photo-physiological responses of seagrass were measured using pulse amplitude modulated (PAM) fluorometry (Diving PAM, Walz, Germany) after the 40 days of being cultured. One apical shoot per aquarium was chosen randomly and placed in a clear container $(8 \mathrm{~L})$ with seawater equilibrated to the experimental condition it was previously reared at. After 15 min dark adaptation, saturation pulse $(0.8 \mathrm{~s})$ was applied to determine the maximum dark-adapted quantum yield of $\Phi_{\text {PSII }}\left(\mathrm{F}_{\mathrm{v}} / \mathrm{F}_{\mathrm{m}}\right)$ measured at the third fully developed leaf. Rapid light curve (RLC) was generated from relative electron transport rate (rETR) using 8 consecutive light levels of 155, 312, 488, 724, 992, 1406, 1926, and $2922 \mu$ mol photons $\mathrm{m}^{-2} \mathrm{~s}^{-1}$ applied every $10 \mathrm{~s}$ intervals. Derived RLC photosynthetic parameters including $\alpha$ (photosynthetic efficiency; the initial slope of the RLC before the saturation occurred), $\beta$ (slope of the RLC when the photoinhibition occurred), maximum relative electron transport rate $\left(\mathrm{rETR}_{\max }\right.$ ), and $\mathrm{E}_{\mathrm{k}}$ (minimum saturating irradiance) were calculated according to Platt et al. ${ }^{42}$, fitted using the Port method in the R Phytotools package ${ }^{43}$.

Seagrass carbon and nitrogen content. Two shoots of seagrass that were not used for the above experiments were taken from each aquarium after the 40 days of culture. Epiphytes were scraped off of the seagrass 
leaves, and then they were divided into the above-ground part (leaves) and below-ground part (rhizomes and roots). Thereafter, all samples were dried $\left(60^{\circ} \mathrm{C}\right)$ for 7 days and the above- and below-ground parts of each of the two shoots were ground with a mortar and pestle into a homogenized fine powder. Ten mg of powder was weighed using an electronic balance (HR-202i, Japan) from each sample, and the carbon and nitrogen were measured the using CN analyzer (Sumigraph NC-22A, Japan).

Sea urchin feeding and fecal production rate. To evaluate the sea urchins and seagrass interactive effects, feeding and fecal production rate of the sea urchins fed with the 2 seagrass treatments (experimental and control seagrass) were measured. All sea urchins were starved for 5 days after 35 days acclimation under the 4 experimental conditions. After starvation and taking all feces from each container, sea urchins in each of the 4 experimental conditions were fed with seagrass leaves that were cultured for 40 days under the same conditions as the sea urchins were cultured (experimental seagrass). Seagrass leaves ( $3.5 \mathrm{~g}$, blot dried) were added to each container with the sea urchins. After 2 days, all the remnant leaves were collected, blotted dry, and weighed to calculate the feeding rate ( $\mathrm{g}$ leaves ind $\left.\mathrm{d}^{-1} \mathrm{day}^{-1}\right)$. Additionally, all feces were collected from each container by filtering the seawater using pre-combusted $\left(550^{\circ} \mathrm{C}, 4 \mathrm{~h}\right)$ and pre-weighed fiberglass filter (Whatman GF/C). After removing all small remnant leaves using tweezers, each filter was dried at $60{ }^{\circ} \mathrm{C}$ until constant weight. The fecal production rate was calculated by subtracting the weight of filter containing feces with the filter weight ( $g$ dry feces ind ${ }^{-1}$ day $^{-1}$ ). Additionally, to evaluate the carbon and nitrogen absorption efficiency, the dried feces were ground into a powder, and ten $\mathrm{mg}$ samples were weighed and fecal carbon and nitrogen content were measured with CN analyzer (Sumigraph NC-22A, Japan). Absorption efficiencies of carbon and nitrogen by sea urchin were calculated by the following formula:

$$
\text { Absorption efficiency }(\%)=\frac{\text { element }_{\text {leaves }}-\text { element }_{\text {feces }}}{\text { element }_{\text {leaves }}} \times 100 \text {. }
$$

After the feeding experiment of experimental seagrass and the following respiration and ammonium excretion measurements detailed below, the same sea urchins were starved again for another 5 days. Thereafter all sea urchins were fed with the seagrass leaves cultured under the control condition (control seagrass). Two days later, the same procedure as above was repeated to measure the feeding and fecal production rate.

Sea urchin respiration and ammonium $\left(\mathrm{NH}_{4}{ }^{+}\right)$excretion rate. Respiration and ammonium $\left(\mathrm{NH}_{4}{ }^{+}\right)$ excretion rates of the sea urchins were measured just after the experimental and control seagrass feeding experiments, respectively. The next day after the feeding experiment, sea urchins were placed individually in $450 \mathrm{~mL}$ glass containers with a magnetic stirrer. After $24 \mathrm{~h}$ acclimation in continuously flowing experimental seawater, each glass container was closed tightly without headspace, and oxygen concentrations were measured 3 times at 0, 30, 60 min using FIBOX fiberoptic oxygen meter (Presens $\mathrm{GmbH}$, Germany). Sea urchin respiration rate ( $\mu \mathrm{mol} \mathrm{O} \mathrm{L}^{-1} \mathrm{~h}^{-1} \mathrm{~g}^{-1}$ ) was calculated by dividing the oxygen concentration change with seawater volume, incubation time, and wet weight (HR-200, A\&D, Japan) of the sea urchin.

Concurrently with the respiration measurement, the ammonium $\left(\mathrm{NH}_{4}{ }^{+}\right)$excretion rate was measured by sampling seawater $(1 \mathrm{~mL})$ just before closing and just after opening each glass container containing sea urchins. Working reagent $(250 \mu \mathrm{L})$ which consisted of borate buffer, sodium sulfite, and orthophthaldialdehyde (OPA) solution was added to each sample and incubated $\left(2 \mathrm{~h}\right.$ ) in the dark (following Holmes et al. ${ }^{44}$ ). The $\mathrm{NH}_{4}{ }^{+}$amount was measured colorimetrically (360 nm, UV-1800, Shimadzu, Japan), and the ammonium excretion rate (nmol $\mathrm{NH}_{4}{ }^{+} \mathrm{h}^{-1} \mathrm{~g}^{-1}$ ) was calculated from the change of $\mathrm{NH}_{4}{ }^{+}$concentration between the end and initial concentration, divided by seawater volume and wet weight of the sea urchin. After the ammonium excretion measurement, the sea urchins were starved to conduct the control seagrass feeding experiment, and then the same procedure was conducted again. All experimental protocols were approved by the University of the Ryukyus, and experiments were performed in accordance with appropriate guidelines and regulations, and in compliance with ARRIVE guidelines.

Statistical analysis. All statistical analyses were calculated in R version $4.0 .1^{45}$ using RStudio version 1.3.959 ${ }^{46}$. All the data were checked for normality with the Shapiro-Wilk test and homogeneity of variances with the Levene's test. Seagrass leaf growth, photo-physiological parameters, carbon and nitrogen content, and leaf $\mathrm{C}: \mathrm{N}$ ratio were analyzed using two-way ANOVA with $\mathrm{pCO}_{2}$ and temperature as fixed factors. Data were transformed to meet assumptions of normality such as $\mathrm{F}_{\mathrm{v}} / \mathrm{F}_{\mathrm{m}}$ ( $\mathrm{x}^{4}$ transformed), $\beta$ (square-root(x) transformed), and $\mathrm{E}_{\mathrm{k}}(\log 10(\mathrm{x})$ transformed). Sea urchin fecal production, respiration (square-root $(\mathrm{x})$ transformed), and ammonium $\left(\mathrm{NH}_{4}^{+}\right)$excretion rate were analyzed using three-way ANOVA with $p \mathrm{CO}_{2}$, temperature, and leaf sources as fixed factors. Data were further analyzed using Tukey's HSD post-hoc test when the result of ANOVA test showed a significant interaction between the factors.

Data of seagrass leaf plastochrone interval $\left(\mathrm{P}_{\mathrm{L}}\right)$ and sea urchin feeding rate was analyzed using Generalized Linear Model (GLM). Inverse Gaussian was used to analyzed $\mathrm{P}_{\mathrm{L}}$ with $p \mathrm{CO}_{2}$, temperature and their interaction were used as model variables. Quasi-Poisson was used to analyze sea urchin feeding rate with $p \mathrm{CO}_{2}$, temperature, leaf sources, and their interactions were used as model variables. When the interaction between independent variables was found, multiple pairwise comparisons analysis (Tukey-Kramer test) were applied using the multcomp package ${ }^{47}$. 
Received: 22 December 2020; Accepted: 18 June 2021

Published online: 30 June 2021

\section{References}

1. Duarte, C. M. \& Chiscano, C. L. Seagrass biomass and production: A reassessment. Aquat. Bot. 65, 159-174 (1999).

2. Boon, P. I., Moriarty, D. J. W. \& Saffigna, P. G. Rates of ammonium turnover and the role of amino-acid deamination in seagrass (Zostera capricorni) beds of Moreton Bay, Australia. Mar. Biol. 91, 259-268 (1986)

3. Smith, S. V. Marine macrophytes as a global carbon sink. Science 211, 838-840 (1981).

4. Scoffin, T. P. The trapping and binding of subtidal carbonate sediments by marine vegetation in Bimini Lagoon, Bahamas. J. Sediment. Res. 40, 249-273 (1970).

5. Robblee, M. B. \& Zieman, J. C. Diel variation in the fish fauna of a tropical seagrass feeding ground. Bull. Mar. Sci. 34, 335-345 (1984).

6. Orth, R. J. et al. A global crisis for seagrass ecosystems. Bioscience 56, 987-996 (2006).

7. Short, F. T. \& Neckles, H. A. The effects of global climate change on seagrasses. Aquat. Bot. 63, 169-196 (1999).

8. Unsworth, R. K. F., Nordlund, L. M. \& Cullen-Unsworth, L. C. Seagrass meadows support global fisheries production. Conserv. Lett. 12, e12566 (2019).

9. Barber, B. J. \& Behrens, P. J. Effects of elevated temperature on seasonal in situ leaf productivity of Thalassia testudinum Banks ex König and Syringodium filiforme Kützing. Aquat. Bot. 22, 61-69 (1985).

10. Marsh, J. A., Dennison, W. C. \& Alberte, R. S. Effects of temperature on photosynthesis and respiration in eelgrass (Zostera marina L.). J. Exp. Mar. Biol. Ecol. 101, 257-267 (1986).

11. Lee, K. S., Park, S. R. \& Kim, Y. K. Effects of irradiance, temperature, and nutrients on growth dynamics of seagrasses: A review. J. Exp. Mar. Biol. Ecol. 350, 144-175 (2007).

12. Marbà, N. \& Duarte, C. M. Mediterranean warming triggers seagrass (Posidonia oceanica) shoot mortality. Glob. Change Biol. 16, 2366-2375 (2010).

13. Kim, M. et al. Influence of water temperature anomalies on the growth of Zostera marina plants held under high and low irradiance levels. Estuaries Coasts 43, 463-476 (2020).

14. Zimmerman, R. C., Kohrs, D. G., Steller, D. L. \& Alberte, R. S. Impacts of $\mathrm{CO}_{2}$ enrichment on productivity and light requirements of eelgrass. Plant Physiol. 115, 599-607 (1997).

15. Palacios, S. L. \& Zimmerman, R. C. Response of eelgrass Zostera marina to $\mathrm{CO}_{2}$ enrichment: Possible impacts of climate change and potential for remediation of coastal habitats. Mar. Ecol. Prog. Ser. 344, 1-13 (2007).

16. Jiang, Z. J., Huang, X. P. \& Zhang, J. P. Effects of $\mathrm{CO}_{2}$ enrichment on photosynthesis, growth, and biochemical composition of seagrass Thalassia hemprichii (Ehrenb.) Aschers. J. Integr. Plant Biol. 52, 904-913 (2010)

17. Beer, S. \& Koch, E. Photosynthesis of marine macroalgae and seagrasses in globally changing $\mathrm{CO}_{2}$ environments. Mar. Ecol. Prog. Ser. 141, 199-204 (1996).

18. Repolho, T. et al. Seagrass ecophysiological performance under ocean warming and acidification. Sci. Rep. 7, 41443 (2017).

19. Tomas, F., Martínez-Crego, B., Hernán, G. \& Santos, R. Responses of seagrass to anthropogenic and natural disturbances do not equally translate to its consumers. Glob. Change Biol. 21, 4021-4030 (2015).

20. Burnell, O. W., Russell, B. D., Irving, A. D. \& Connell, S. D. Eutrophication offsets increased sea urchin grazing on seagrass aused by ocean warming and acidification. Mar. Ecol. Prog. Ser. 485, 37-46 (2013).

21. Kurihara, H., Yin, R., Nishihara, G. N., Soyano, K. \& Ishimatsu, A. Effect of ocean acidification on growth, gonad development and physiology of the sea urchin Hemicentrotus pulcherrimus. Aquat. Biol. 18, 281-292 (2013).

22. Catarino, A. I., Bauwens, M. \& Dubois, P. Acid-base balance and metabolic response of the sea urchin Paracentrotus lividus to different seawater pH and temperatures. Environ. Sci. Pollut. Res. 19, 2344-2353 (2012).

23. Arnold, T. et al. Ocean acidification and the loss of phenolic substances in marine plants. PLoS One 7, e35107 (2012).

24. Hernán, G. et al. Seagrass (Posidonia oceanica) seedlings in a high- $\mathrm{CO}_{2}$ world: from physiology to herbivory. Sci. Rep. 6, 38017 (2016).

25. Nguyen, K. D. T. et al. Upper temperature limits of tropical marine ectotherms: Global warming implications. PLoS ONE 6, e29240 (2011).

26. Agawin, N. S. R., Duarte, C. M., Fortes, M. D., Uri, J. S. \& Vermaat, J. E. Temporal changes in the abundance, leaf growth and photosynthesis of three co-occurring Philippine seagrasses. J. Exp. Mar. Biol. Ecol. 260, 217-239 (2001).

27. Kurihara, H., Wouters, J. \& Yasuda, N. Seasonal calcification of the coral Acropora digitifera from a subtropical marginal Okinawa reef under ocean acidification. Coral Reefs 38, 443-454 (2019).

28. Koch, M., Bowes, G., Ross, C. \& Zhang, X. H. Climate change and ocean acidification effects on seagrasses and marine macroalgae. Glob. Change Biol. 19, 103-132 (2013).

29. Sage, R. F. \& Kubien, D. S. The temperature response of $C_{3}$ and $C_{4}$ photosynthesis. Plant Cell Environ. 30, 1086-1106 (2007).

30. O'Connor, M. I. Warming strengthens an herbivore-plant interaction. Ecology 90, 388-398 (2009).

31. Campbell, J. E. \& Fourqurean, J. W. Effects of in situ $\mathrm{CO}_{2}$ enrichment on the structural and chemical characteristics of the seagrass Thalassia testudinum. Mar. Biol. 160, 1465-1475 (2013).

32. Moulin, L., Grosjean, P., Leblud, J., Batigny, A. \& Dubois, P. Impact of elevated $p \mathrm{CO}_{2}$ on acid-base regulation of the sea urchin Echinometra mathaei and its relation to resistance to ocean acidification: A study in mesocosms. J. Exp. Mar. Biol. Ecol. 457, 97-104 (2014).

33. Stumpp, M., Trübenbach, K., Brennecke, D., Hu, M. Y. \& Melzner, F. Resource allocation and extracellular acid-base status in the sea urchin Strongylocentrotus droebachiensis in response to $\mathrm{CO}_{2}$ induced seawater acidification. Aquat. Toxicol. 110-111, 194-207 (2012).

34. Thomsen, J. \& Melzner, F. Moderate seawater acidification does not elicit long-term metabolic depression in the blue mussel Mytilus edulis. Mar. Biol. 157, 2667-2676 (2010).

35. Marčeta, T. et al. Do males and females respond differently to ocean acidification? An experimental study with the sea urchin Paracentrotus lividus. Environ. Sci. Pollut. Res. 27, 39516-39530 (2020).

36. Uthicke, S., Soars, N., Foo, S. \& Byrne, M. Effects of elevated $p \mathrm{CO}_{2}$ and the effect of parent acclimation on development in the tropical Pacific sea urchin Echinometra mathaei. Mar. Biol. 160, 1913-1926 (2013).

37. Atwood, T. B. et al. Predators help protect carbon stocks in blue carbon ecosystems. Nat. Clim. Change 5, 1038-1045 (2015).

38. Scott, A. L. et al. The role of herbivory in structuring tropical seagrass ecosystem service delivery. Front. Plant Sci. 9, 127 (2018).

39. Lewis, E. \& Wallace, D. Program developed for $\mathrm{CO}_{2}$ system calculations. Ornl/Cdiac 105, 1-21 (1998).

40. Dickson, A. G. \& Millero, F. J. A comparison of the equilibrium constants for the dissociation of carbonic acid in seawater media. Deep Sea Res. Part A Oceanogr. Res. Pap. 34, 1733-1743 (1987).

41. Short, F. T. \& Duarte, C. M. Methods for the measurement of seagrass growth and production. In Global Seagrass Research Methods (eds. Short, F. T. \& Coles, R. G.) 155-182 (Elsevier Science, 2001). https://doi.org/10.1016/b978-044450891-1/50009-8.

42. Platt, T., Gallegos, C. L. \& Harrison, W. G. Photoinhibition of photosynthesis in natural assemblages of marine phytoplankton. J. Mar. Res. 38, 103-111 (1980). 
43. Silsbe, G. M. \& Malkin, S. Y. Phytotools: phytoplankton production tools. An R Packag. available CRAN. https://cran.r-project. $\mathrm{org} /$ web/packages/phytotools/index.html. Accessed 7 July 2020 (2015).

44. Holmes, R. M., Aminot, A., Kérouel, R., Hooker, B. A. \& Peterson, B. J. A simple and precise method for measuring ammonium in marine and freshwater ecosystems. Can. J. Fish. Aquat. Sci. 56, 1801-1808 (1999).

45. R Core team. R: A Language and Environment for Statistical Computing. (R Foundation for Statistical Computing, 2020).

46. Team, Rs. RStudio: Integrated Development for R. (RStudio, Inc., 2015)

47. Hothorn, T., Bretz, F. \& Westfall, P. Simultaneous inference in general parametric models. Biom. J. 50, 346-363 (2008).

\section{Acknowledgements}

We thank the Sesoko Station staffs, Tropical Biosphere Research Center, University of the Ryukyus, and Okinawa Prefectural Sea Farming Center for their support. This work was supported by funding from the Japan Society for the Promotion of Science (JSPS) KAKENHI, grant number: 16H017929, University of the Ryukyus Research Incentive Grant for KAKENHI Acquisition and Marine Pew Fellow Program.

\section{Author contributions}

H.K. designed the experiment and V.L. conceived the experiments. V.L. and H.K. analyzed the data, prepared figures and/or tables, wrote and reviewed the manuscript and approved the final draft.

\section{Competing interests}

The authors declare no competing interests.

\section{Additional information}

Supplementary Information The online version contains supplementary material available at https://doi.org/ 10.1038/s41598-021-92989-0.

Correspondence and requests for materials should be addressed to H.K.

Reprints and permissions information is available at www.nature.com/reprints.

Publisher's note Springer Nature remains neutral with regard to jurisdictional claims in published maps and institutional affiliations.

(c) (i) Open Access This article is licensed under a Creative Commons Attribution 4.0 International License, which permits use, sharing, adaptation, distribution and reproduction in any medium or format, as long as you give appropriate credit to the original author(s) and the source, provide a link to the Creative Commons licence, and indicate if changes were made. The images or other third party material in this article are included in the article's Creative Commons licence, unless indicated otherwise in a credit line to the material. If material is not included in the article's Creative Commons licence and your intended use is not permitted by statutory regulation or exceeds the permitted use, you will need to obtain permission directly from the copyright holder. To view a copy of this licence, visit http://creativecommons.org/licenses/by/4.0/.

(C) The Author(s) 2021 